> Gi respons på artikler gjennom artiklenes kommentarfelt på tidsskriftet.no.

Innleggene publiseres fortløpende på Tidsskriftets nettside og et utvalg

av innleggene publiseres også i papirutgaven i spalten «Brev til redaktøren».

Redaksjonen forbeholder seg retten til å foreta redaksjonelle endringer.

Forfattere av vitenskapelige artikler har tilsvarsrett, jf. Vancouver-gruppens regler.

\section{Re: Tvilsom begrunnelse for reservasjonsmulighet}

Andreas Eriksen hevder at den typen moralsk integritet som reservasjonsadgang vil beskytte, «er en passiv versjon av integritet som først og fremst handler om å beskytte aktørens selvbilde» (1). Dette mener jeg ikke er riktig.

Reservasjon har tre viktige hensikter: Reservasjonslegen slipper å gjøre noe som oppfattes som alvorlig galt, hun/han får unnlate å skade en tredjeperson, fosteret, og hun/han får beskytte egen integritet (2). Konsistens og moralsk integritet kan fordre aktive handlinger også, slik som politisk stemmegivning, men legekontoret er ikke arenaen for dette.

Videre skriver Eriksen: «Man er (...) allerede medvirkende til drap ved å ha en rolle i en institusjon som utfører disse drapene.» Dette synet er problematisk. Er en gynekolog virkelig medansvarlig for at det utføres aborter, når hun/han selv aktivt har reservert seg og dermed tatt avstand? Innebærer det å betale skatt tilslutning til, og medansvar for, alt staten bruker pengene på? Naturrettstradisjonen har et velutviklet rammeverk for å vurdere moralsk betydning av samarbeid med uetiske handlinger (3). Det identifiserer viktige vesens- og gradsforskjeller.

Ifølge naturretten er handlingens intensjon spesielt viktig. Eriksen kritiserer påstanden om at å henvise kan oppleves som å stille seg bak pasientens intensjon om abort. «Leger trenger på ingen måte dele pasientens moralske valg om å ta abort», skriver han. Her legger han til grunn noe jeg synes er et problematisk intensjonsbegrep. Ifølge naturrettstradisjonen er intensjon en mental tilstand som resulterer i handling (4). Intensjonen er ikke det vi skulle ønske ville skje, men det vi faktisk velger. I intensjonen inngår både handlingens formål og midler. I denne forståelsen er aborthenvisning nettopp å velge abort - å henvise innebærer logisk å «gi ordre om» det som det henvises til. Én reservasjonslege beskrev aborthenvisning som «å signere en dødsdom» (5). Selv om dette synet kan utfordres av konkurrerende forståelser, bygger det på et filosofisk fundament. Det taler for at samvittighetsoverbevisningene som springer ut av dette synet, bør tolereres.

Jeg får inntrykk av at Eriksen mener leger trygt kan legge vekk sin egen etiske refleksjon og lojalt følge staten i alt. Men dette er farlig, slik Charlotte Haug viser med eksempel fra Kinas ettbarnspolitikk (6). En konsekvens av Eriksens syn er at leger må pålegges å utføre eller henvise til eutanasi hvis dette en gang blir tillatt.

Kunne vi få til en kultur for å tolerere hverandres syn i viktige etiske spørsmål? Da ville vi ha en viktig etisk beredskap neste gang medisinen blir fristet til å begå etiske feiltrinn. Slik jeg ser det, finnes det i grunn bare to alternativer: Enten tar staten avgjørelsene i etiske kontroverser og dikterer legenes praksis, eller så regnes legen som en selvstendig moralsk handlende, som må stå til regnskap overfor egen samvittighet, kolleger og samfunn. Det siste er i det lange løp å foretrekke - også for pasientene (7).

\section{Morten Magelssen}

magelssen@gmail.com

Morten Magelssen (f. 1978) er ph.d.-stipendiat.

Ingen oppgitte interessekonflikter

\section{Litteratur}

1. Eriksen A. Tvilsom begrunnelse for reservasjonsmulighet. Tidsskr Nor Legeforen 2014; 134: 505-6.

2. Magelssen M. Menneskeverd i klinikk og politikk. Bioetikk i lys av kristen tro. Oslo: Lunde Forlag, 2013.
3. Sulmasy DP. What is conscience and why is respect for it so important? Theor Med Bioeth 2008; 29: 135-49.

4. Finnis J, Grisez G, Boyle J. «Direct» and «indirect»: a reply to critics of our action theory. Thomist 2001; 65: 1-44.

5. Nordberg EMK, Skirbekk H, Magelssen M. Conscientious objection to referrals for abortion: pragmatic solution or threat to women's rights? BMC Med Ethics 2014; 15: 15

6. Haug C. Dilemmaenes århundre. Tidsskr Nor Legeforen 2014; 134: 493

7. Haaland E. Et gode for pasient, samfunn og demokrati. Aftenposten 21.2.2014. http://aftenposten.no/meninger/kronikker/Et-gode-for-pasient_-samfunn-ogdemokrati-7475619.html (18.3.2014).

\section{A. Eriksen svarer:}

Ut fra dette innlegget kan det se ut som om Morten Magelssen har skiftet syn på integritet. Magelssen er medforfatter av notatet fra Civita (1) jeg diskuterer i kommentarartikkelen Tvilsom begrunnelse for reservasjonsmulighet, og der står det at reservasjonen beskytter integritet forstått som «ubrutt helhet»- man bevarer sitt moralske selvbilde i jobben (1, s 6). I sin kommentar til min artikkel hevder Magelssen at min tolkning av dette som en passiv versjon av integritet, som først og fremst handler om å beskytte aktørens selvbilde, er uriktig. Integritet «kan fordre aktive handlinger også», men «legekontoret er ikke arenaen for dette». Hva har denne integritetsforståelsen da med legers reservasjon å gjøre?

Videre hevder Magelssen at aktører som har en rolle i en institusjon, ikke trenger å ta medansvar for handlinger som utføres i institusjonens navn. Man kan reservere seg mot «uakseptable og dypt umoralske» drap $(1, \mathrm{~s} 7)$ og uten medansvar la kolleger gjøre det. Igjen, hvis dette er å utøve integritet, mener jeg det framstår som en betenkelig dygd.

Magelssen argumenterer mot begrepet medansvar med at vi som borgere ikke har ansvar for hva staten bruker skattepengene på. Men dersom den norske stat brukte skattepengene mine på et moralsk forkastelig vis, ville det ikke vært unaturlig av meg å ta ansvar i form av protest og sivil ulydighet. Og ansvaret ville vært betydelig dersom jeg representerte institusjonen som faktisk gjennomførte det umoralske, da min rolle i større grad støtter handlingene.

Jeg skriver at leger ikke trenger å dele den enkelte pasients valg om abort. De deler profesjonens intensjon om å gi pasienten rettmessig hjelp. Her opererer jeg ifølge Magelssen med et problematisk intensjonsbegrep. Han mener at vi kan slutte fra legens betydelige bidrag i årsakskjeden til at legen deler pasientens intensjon om abort $(1$, s 6$)$. I så fall deler f.eks. advokater som forsvarer ytringsfrihet sine klienters intensjoner om trusler. Men å oppfylle rettigheter er ikke det samme som å støtte den konkrete handlingen som rettighetene er et middel til.

Magelssen har fått inntrykk av at jeg mener at leger bør følge staten $i$ alt. I virkeligheten angriper jeg tanken om at profesjonsrollen alltid gir moralsk belegg for handling. Bare legitime rolleinstrukser begrunner handling. Legitimitet har en nedre moralsk terskel. Terskelen markerer overgangen fra rimelig uenighet til forakt for moralprinsipper. Autoritære regimers politikk er altså ikke noe motargument mot det jeg skriver.

Mitt syn har ifølge Magelssen den konsekvens at leger må pålegges å utføre eller henvise til eutanasi hvis dette blir tillatt. Det er underlig, for jeg argumenterer jo ikke for at leger må pålegges dette i abortspørsmål. Istedenfor skriver jeg: «Samfunnet må ta stilling til hvorvidt samvittighetsfriheten kan institusjonaliseres i ulike offentlige roller uten at den blir en urimelig byrde for pasientene.»

Men institusjonalisering av rettigheter er uansett ikke ønskelig, hevder Magelssen. Han vil at legen skal regnes som «selvstendig 